\title{
Theodulf of Orléans and the Ark of the Covenant: A New Allegorical Interpretation at Germigny-des-Prés
}

\section{Gillian Mackie}

Volume 32, numéro 1-2, 2007

URI : https://id.erudit.org/iderudit/1069593ar

DOI : https://doi.org/10.7202/1069593ar

Aller au sommaire du numéro

\section{Éditeur(s)}

UAAC-AAUC (University Art Association of Canada | Association d'art des universités du Canada)

\section{ISSN}

0315-9906 (imprimé)

1918-4778 (numérique)

Découvrir la revue

\section{Citer cet article}

Mackie, G. (2007). Theodulf of Orléans and the Ark of the Covenant: A New Allegorical Interpretation at Germigny-des-Prés. RACAR : Revue d'art canadienne / Canadian Art Review, 32(1-2), 45-58.

https://doi.org/10.7202/1069593ar

\section{Résumé de l'article}

L'iconographie unique de la mosaïque de l'abside créée par Théodulf, évêque d'Orléans, à l'oratoire de Germigny-des-Prés en 806, contient le seul sujet hébreu et non chrétien à y avoir survécu sur un autel chrétien : une image de l'Arche d'Alliance, encadrée de deux chérubins, fidèle aux textes de l'Ancien Testament. L'image est analysée non seulement dans son sens littéral en tant qu'illustration historique d'un texte, mais aussi en rapport avec les nombreuses allégories de l'Arche qui firent l'objet de discussions exégétiques à l'époque. Des preuves sont fournies à l'effet que, parmi les multiples strates de sens coexistant sous la surface de cette image, pourrait exister une Vierge Marie trônant entre deux chérubins et que Théodulf, malgré l'absence d'éloges à la Vierge Marie dans ses propres textes, aurait pu inscrire - en vertu de son passé, de ses intérêts et de sa formation - cette allégorie cachée dans l'image non iconique qu'il avait érigée au-dessus de son autel. Ainsi, dans ses dévotions personnelles, pouvait-il saluer la Vierge en conformité avec sa position iconophobe et dans le respects êtres saints de sa foi.
Tous droits réservés @ UAAC-AAUC (University Art Association of Canada | Association d'art des universités du Canada), 2007
Ce document est protégé par la loi sur le droit d'auteur. L'utilisation des services d'Érudit (y compris la reproduction) est assujettie à sa politique d'utilisation que vous pouvez consulter en ligne.

https://apropos.erudit.org/fr/usagers/politique-dutilisation/ 


\title{
Theodulf of Orléans and the Ark of the Covenant: A New Allegorical Interpretation at Germigny-des-Prés
}

\author{
GILIIIAN MACKIE, UNIVERSIIY OF VICTORIA
}

\begin{abstract}
Résumé
L'iconographie unique de la mosaïque de l'abside créée par Théodulf, évêque d'Orléans, à l'oratoire de Germigny-des-Prés en 806, contient le seul sujet hébreu et non chrétien à y avoir survécu sur un autel chrétien : une image de l'Arche d'Alliance, encadrée de deux chérubins, fidèle aux textes de l'Ancien Testament. L'image est analysée non seulement dans son sens littéral en tant qu'illustration historique d'un texte, mais aussi en rapport avec les nombreuses allégories de l'Arche qui firent l'objet de discussions exégétiques à l'époque. Des preuves sont fournies à l'effet que, parmi les multiples strates de
\end{abstract}

sens coexistant sous la surface de cette image, pourrait exister une Vierge Marie trônant entre deux chérubins et que Théodulf, malgré l'absence d'éloges à la Vierge Marie dans ses propres textes, aurait pu inscrire - en vertu de son passé. de ses intérêts et de sa formation - cette allégorie cachée dans l'image non iconique qu'il avait érigée au-dessus de son autel. Ainsi, dans ses dévotions personnelles, pouvait-il saluer la Vierge en conformité avec sa position iconophobe et dans le respects êtres saints de sa foi.
$\mathrm{T}_{\mathrm{h}}$ he apse mosaic at Germigny-des-Prés, which Theodulf, Bishop of Orléans, placed in his private chapel in $806,{ }^{1}$ is famous both as the oldest wall mosaic of the Christian era to survive in France, and for its unique iconography, which is "without precedent or descendent." The purpose of this paper is to explore this iconography, to note the allegories that have already been attributed to the mosaic image, and to suggest a further meaning that may well be hidden there. For the first time, the possibility that the image of the Hebrew Ark of the Covenant at Germigny-des-Prés is also to be understood as an aniconic representation of the Virgin Mary enthroned between angels will be discussed. But first, the image will be introduced by way of a summary of its iconography, the inscriptions of the patron, Theodulf, Bishop of Orléans, and the relevant literature.

The illustration (fig. 1) shows Theodulf's mosaic. In the centre is the Ark of the Covenant, shown as an open rectangular box overlaid with gold inside and out, with gilded rings and carrying handles, and tilted forward so that its top - or its interior and any possible contents - could be seen. Nineteenthcentury restorations had removed all details of the interior, but Ann Freeman and Paul Meyvaert have recently argued, on the basis of a drawing made by Théodore Chrétin in March 1847 , that the Germigny Ark was shown to be both open and empty. They noted that Chrétin depicted the newly cleaned mosaics with a vertical line descending into the box from its right-hand back corner, as if to define a box-like interior. ${ }^{3}$ This detail did not survive restoration between 1841 and 1856 and is no longer visible. ${ }^{4}$ I suggest that one cannot be certain that the Ark was empty on the basis of Chrétin's drawing and its copies, as the vertical line could well have been the artist's attempt to make sense of the chaotic "interior" of the Ark, which was in need of substantial restoration at that time. In the same vein, Chrétin rationalized the three sets of seven indistinct motifs that can still be seen on the front of the Ark as three rows of five neat panels, another example of his inaccuracy. ${ }^{5}$ Furthermore, in the mosaic itself, the small angels are shown as standing on the back corners of the Ark's cover or propitiatorium. These corners are not included among the areas of restoration that Poilpré lists in her careful study of the restoration history of the Ark. Their presence reinforces the impression of a closed box, with a cloth pulled aside and draped over the front edge. ${ }^{6}$ Such a closed container would harmonize with other Marian allegories in use in the early Middle Ages, such as the enclosed garden, the closed door, and the vase.

The Ark of the Covenant represented the sanctuary in which God dwelt among his people, and symbolized his nearness to them. Its golden cover was the "mercy seat" or propitiatorium, on which the invisible God was seated, adored by two cherubim, also of gold. Theodulf's image illustrates the twenty-fifth chapter of the Book of Exodus accurately, using, with the gold of mosaic tesserae, a splendid substitute for the solid or hammered gold of the text. Two much larger cherubim stretch their wings to touch the sides of the apse, as described in 2 Chronicles, chapter three, which was expounded by Bede (ca. 673-735) in his De Templo, a source that Theodulf quoted at length ${ }^{7}$ in his Opus Caroli Regis. ${ }^{8}$ The Chronicles text read:

In the most holy place he [Solomon] made two cherubim of wood, and overlaid them with gold. The wings of the cherubim together extended twenty cubits: one wing of the one ... touched the wall of the house and the other wing ... touched the wing of the first cherub ... [and] the cherubim stood on their feet, facing the nave. ${ }^{\text {? }}$

Bede, alone among the theologians of his age, taught that the two pairs of angels represent both of God's revelations, the earlier one to the Jews through Moses, and the later one to the Gentiles through Jesus Christ. In the Germigny mosaic, the smaller cherubim gesture with both hands towards the Ark; the 
Figure I. The Apse-Mosaic at Germigny-des-Prés (Photo: Michel Gauthier, from "Église de Germigny: la Mosaïque," visitor pamphlet available at the church).

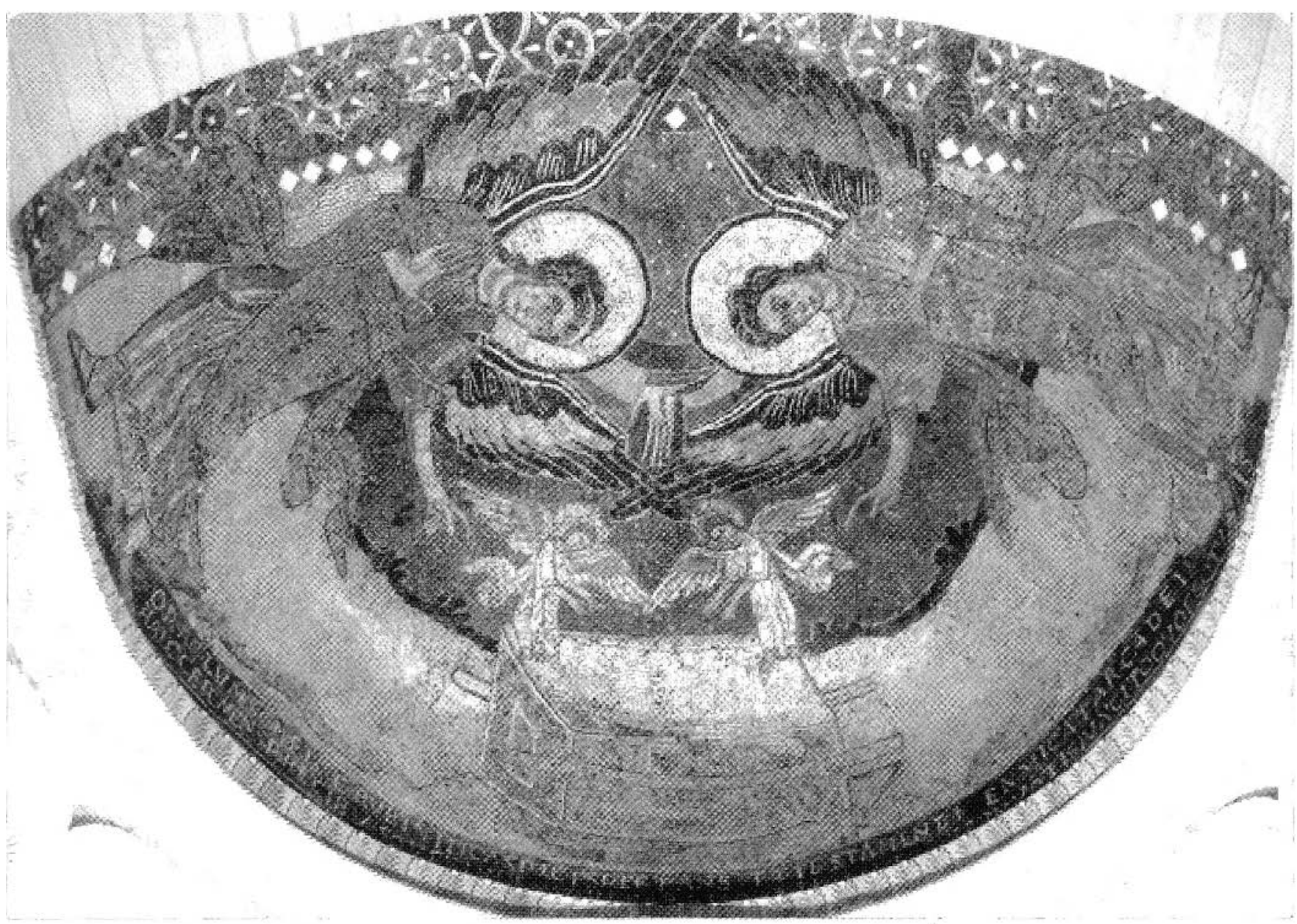

larger ones point downwards with their inner hands towards the Ark and beyond it to the altar below, while their outer hands are raised towards the spectator in the gesture of speech. Meyvaert and Freeman have pointed out that this altar was the location of Christ's presence in the sacraments. ${ }^{10}$ According to the biblical texts, God commanded Moses to place the Tables of the Law with the Ten Commandments engraved upon them in the Ark. They were accompanied by the Menorah or seven-branched candlestick to light the Ark's interior, the Basket of Manna or bread offered to God as a sacrificial offering, and the Rod of Aaron, symbol of his priestly authority. ${ }^{11}$ It is these contents that would perhaps have been shown at Germigny, if indeed the Ark was depicted as an open structure. There is, however, an additional reason to suppose that Theodulf's Ark was portrayed as a covered container, namely that the contents were considered so holy that sight of them posed serious danger to the viewer. ${ }^{12}$ Finally, the mosaic shows a hand emerging from the starry heavens above. Traditionally, this would indicate that
God's own instructions, as recorded in the Book of Exodus, are illustrated below. However, Freeman and Meyvaert have suggested an additional meaning for the image, namely, that its vertical crease symbolizes the wounds Christ suffered at the Crucifixion, which he retained even after his Resurrection. ${ }^{13}$

Around the bowl of the apse an inscription in the mosaic itself names Theodulf as its creator. It reads: "Behold the holy oracle and the cherubim; and contemplate the splendour of God's ark and, while you contemplate and are eager to move the God of Thunder with your prayers, include Theodulf, I beg you, in your supplications." 14 Theodulf's name on the apse mosaic at Germigny-des-Prés confirms his role in the design of its iconography. Freeman has established that he was also the primary author of the Opus Caroli Regis, a treatise written around the year $791 \mathrm{AD}$ in the name of Charlemagne. ${ }^{15}$ The Opus Caroli Regis consisted of a policy statement rebutting the new position on images of the Eastern Church, which had been set out in the Second Council of Nicaea in 787. Nicaea II once 
again allowed the creation and veneration of images, which had been banned during the first period of iconoclasm. However, this new policy was understood in the West to support the worship of images, as opposed to their veneration, a misunderstanding that probably stemmed from a defective translation of the Greek original made by the papal librarian, Anastasius. The result was that a full statement of the Carolingian position on images was prepared for the Opus Caroli Regis. This text can be assumed to have presented not only Charlemagne's and his advisors' point of view on this issue, but also Theodulf's own, both as primary author, and as the only Visigoth in the inner circle of Charlemagne's court. It was shelved as the result of its divergence from the position taken by Pope Hadrian I on the image question, ${ }^{16}$ and was never circulated during Theodulf's lifetime, though one can assume that he did not forget the arguments he had made in this major work.

Theodulf's personal position as set forth in the Opus Caroli Regis was that of an iconodule. Inspired by the detailed texts in the Bible recording God's words to Moses about the Tabernacle and the Temple of Solomon, Theodulf devoted several important chapters in the Opus Caroli Regis to them. ${ }^{17}$ There he summarized many of the arguments of earlier theologians, and justified the special status of the Ark, which was the only image identified as a "res sacrata," a holy object, to be included among the group of most sacred items. These were the Bible itself, the Sacraments, the liturgical vessels, the Ark of the Covenant, and the Cross, all of which the Bible lists as divinely consecrated. Among these, the Ark's special status depended on its divine origin: God was the author of its plan, which he imparted to Moses in his own words. Since every detail had been sanctioned by God, subsequent images that adhered faithfully in detail to God's plan were believed to be exempt from the prohibitions of the Second Commandment concerning graven images, as was the original. This would account for Theodulf's choice of it as the image to be portrayed over the altar in his chapel at Germignydes-Prés. ${ }^{18}$ The problem I will discuss here is whether the Germigny image should be taken simply at its face value as an illustration of the texts of Exodus and the Second Book of Chronicles, and thus as a reminder of the unique res sacrata that God had prescribed as container of his revelation to Moses and the Hebrews. ${ }^{19}$ In this case we might conclude that Theodulf had acquired the special interest in the Old Testament that would have been normal for a Visigoth raised in the early church in Spain. ${ }^{20}$ But Freeman and Meyvaert have gone much further than this in their recent article. ${ }^{21}$ They have interpreted the Germigny composition in a compelling way as representing the fulfillment of the Ark's promise: God's plan of redemption for humanity through the Incarnation, Death, and Resurrection of Christ. This plan was symbolized both by the "empty" Ark and by the wounds that Christ still bore when he rose from the dead, and which are represented in the hand of God in the mosaic at Germigny-des-Prés. Their arguments, while convincing, are founded on features of the mosaics that may well not be original. Even if one accepts their interpretation, it does not eliminate the validity of considering the mosaic's other possible meanings, namely allegorical interpretations that had been sanctioned by the Church Fathers and discussed with interest by the theologians of the Carolingian era. Theodulf, a self-confessed omnivorous reader, will certainly have been aware of these allegories. That multiple meanings and multivalent allegories could coexist as interpretations of a single image was acceptable to the creators of medieval art, and there were many precedents for the idea. I suggest that while Theodulf's representation of the Ark follows the formula of the Old Testament texts, and illustrates the ideas in his Opus Caroli Regis, it also expresses other allegorical meanings, typological equivalents that were well known in the exegesis of his day. These will have included both holy beings and collective entities, among them both Christ and the Church itself. ${ }^{22}$

Allegorical interpretations of the Ark as Christ and as his Church were widely understood in the Carolingian period. These concepts were inherited from the Church Fathers, who had proclaimed Christ himself to be the typological equivalent of the Ark. By the early fifth century Augustine (354-430) had expounded the allegorical meaning of the elements of the Ark in terms of the New Law and of the grace it conferred. ${ }^{23}$ The idea that the Ark also represented the Church was clearly developed by Gregory the Great (540-604), who found an allegorical equivalent for each component of the Ark, from the two cherubim as the two Testaments, to the Mercy Seat as the incarnate Christ. ${ }^{24}$ Gregory's near contemporary in Spain, Isidore of Seville (ca. 560-636), further developed the idea of the Ark as an allegory of the Church. He interpreted its Old Testament elements in Christian terms, seeing the carrying rings as the four Evangelists and the Rod of Aaron as the sceptre of the true pontiff of the Church, Christ himself, who sits above the Ark on the Mercy Seat and intercedes with God on behalf of humanity. ${ }^{25}$ Theodulf, by his own admission, had studied the works of all of these theologians in depth ${ }^{26}$ and their ideas must have been familiar to him: indeed, Freeman has identified the sources in Isidore's teachings of many of the ideas in the Opus Caroli Regis. ${ }^{27}$ Presumably Theodulf was also aware that the Fathers believed the Ark represented an allegory of Christ. Theodulf's surviving body of religious poetry is evidence of his devotion to the Saviour, as is his dedication of his palace chapel to him. The dedication, hinted at in the apse inscription, is confirmed by an entry in the abbatial list of Fleury, of which Theodulf was the fourteenth abbot, concomitantly with his position as bishop of Orléans. ${ }^{28}$ Consecration to the Saviour was not unusual, for it followed the precedent set by the emperor Constantine who 
thus dedicated the Constantinian Basilica in Rome, which would only later be rededicated to the Baptist as San Giovanni in Laterano. Constantine's precedent was followed, for example, by many of the Lombard rulers. ${ }^{29}$ Of course Theodulf, as bishop, need not have been bound by such a convention, and it is likely that the dedication was his personal choice, indicating his devotion to Christ. Theodulf's chapel dedication, as well as his Christ-centred poetry, implies that he is likely to have interpreted the image of the Ark over the altar as both an allegory of Christ and an image of the Church, following the teachings of the Western Fathers. I have already suggested another interpretation of the image at Germigny: that it illustrates the idea of the Ark as a prefiguration of the Virgin Mary. This interpretation depends on links between an era of growing devotion to Mary, especially in Visigothic Spain, and the background of Theodulf as a Spaniard raised in the Visigothic Church.

I will argue that despite lack of definitive proof in the form of poems or other writings by Theodulf in praise of Mary, it is very likely that he shared the interest of his era in Christ's mother, an interest that, like his devotion to Christ, was grounded in the theology of the Western Church Fathers. Just as many churches were dedicated to Christ, devotion to Mary, in both Theodulf's own day and that of his Visigothic forebears in Toulouse, ensured that churches and chapels were named in her honour. These dedications expressed a major interest in the Mother of God at the highest levels of patronage. Most famous of all were the private chapels of the emperors at Constantinople that took her name. Charlemagne, probably in imitation of this precedent, and in recognition of a precious relic, a fragment of Mary's robe that he had received from the empress Eirene, had also dedicated his palace chapel at Aachen to the Virgin, placing the relic inside it. This chapel was consecrated by Pope Leo III in 805 , shortly before Theodulf's chapel was built in 806 . An even earlier dedication to the Virgin was that of La Daurade, the Visigothic kings' palace chapel and royal mausoleum in Toulouse, which originally bore a double dedication to the Virgin and the Saviour. ${ }^{30}$ The golden mosaics for which La Daurade was named were the work of one of the Visigothic kings who held court at Toulouse from 418 to 507, most likely Theodulf II (453-66). This dating would fit with the period soon after 431, when Mary's cult was growing throughout the Christian world as a consequence of the decision of the Council of Ephesus that she was the Mother of God. The La Daurade mosaics celebrated not only her role in the Incarnation, but also in more depth, the visit of the Magi, who had come from the East to bestow gifts and to worship the new-born Christ in his Mother's arms. ${ }^{31}$ Thus, precedents existed not only at the court of Charlemagne but also in once-Visigothic lands for the dedication of a palace chapel to the Virgin. Theodulf, himself probably born and raised in Saragossa and moving to Septimania as a young adult, ${ }^{32}$ can hardly have been unaware of La Daurade, with its splendid mosaics celebrating important episodes from the Virgin's life and Christ's infancy: the Nativity and the Magi cycle. ${ }^{33} \mathrm{La}$ Daurade must have been famous throughout the whole region, and the golden mosaics celebrated in its name may well have kindled Theodulf's enthusiasm for the use of the mosaic medium in his own palace chapel, as well as for a recognition there of Mary's role in the Incarnation. Whereas Charlemagne's choice of the Virgin is evidence of the esteem she enjoyed at the imperial court in Constantinople, the roots of such esteem were planted in both East and West in the period after the Council of Ephesus. The evidence of her new status as Mother of God, which was demonstrated at La Daurade, suggests that Theodulf's apse mosaic may also have a further richness of meaning. Just as the Ark had contained the Old Dispensation revealed by God to Moses, on the allegorical level the Virgin Mary through God's grace fulfills the role of the vessel chosen for the Incarnation of Christ, the New Dispensation. This interpretation has not until now been suggested for the Germigny apse mosaic. ${ }^{34}$

Since no surviving document expressly records Theodulf's devotion to the Virgin Mary, this interpretation must depend at least partly on the context in which Theodulf had been raised as a Visigoth in the Spanish Church, which from earliest times had been especially devoted to the Mother of God. From the time of the Council of Ephesus Mary had been the subject of a substantial amount of monumental art in the West, quite apart from Septimania with its La Daurade. ${ }^{35}$ Although not many of these early apse decorations have survived until today, the few survivors, as well as literary sources, describe her as enthroned between angels, and with the Child upon her knee, in compositions that represent the Incarnation. More rarely, she is shown alone upon her throne, honoured for her role and perhaps for her impending maternity. ${ }^{36}$ The angels constitute her heavenly court, as in Cyprus at both the sixth-century Church of the Virgin at Lythrankomi, and at the seventh-century church at Kiti, where she appears berween the archangels Michael and Gabriel. ${ }^{37}$

The idea that a mystical representation of the Virgin may exist within the image of the Ark of the Covenant at Germigny is suggested by the frequency with which she is described in early medieval sources in terms of allegory. It is also supported by the fact that Theodulf himself was "one Carolingian figure who had no prejudice against allegorical representations." 38 By his own time, the early ninth century, the Virgin was praised, among many other metaphors, as manna, a vase, a closed door, a garden, a fountain, a star, the sun, and the earth. ${ }^{39}$ But in order to understand Theodulf's mosaic Ark as a prefiguration of the Virgin Mary, we need to consider a second group of allegories that were current in the writings of the early Fathers, of Late Antique poets, and in the liturgy. All of these acclaimed the Virgin as allegorically equivalent to various aspects of the He- 
brew tabernacle, including the Temple itself, as well as to the Holy of Holies and its sacred contents, the Ark of the Covenant. Most important among these equivalents in the context of Theodulf's chapel, is the Ark, container of the tablets of the Law that were given to Moses by God himself at Sinai and were inscribed with the text of the Ten Commandments, the "Old Dispensation."

An explicit statement of faith compiled in connection with the Seventh Ecumenical Council that met in Nicaea in 787 gives a summary of the prefigurations that had been employed as types of the Virgin in the preceding iconoclastic period. It reads: "Those who know that the rod and tablets of the Law, the Ark of the Covenant, the menorah, the table and the censer foretell and prefigure the Theotokos Mary, and that these things prefigure her, but that she was born a girl and remained a Virgin after giving birth to God; those who for this reason prefer to represent her in images rather than to symbolize her in these types, may their memory be eternal." ${ }^{20}$ That is, the prefigurations were now considered to be obsolete, in light of the newly permitted veneration of images, but had been accepted and current in the recent past, the time of Theodulf. They would almost certainly have been known to him.

Mary, according to early legends of her infancy recorded in the Book of James, an apocryphal infancy gospel attributed to Christ's brother James, and dating from the mid-second century, was taken to the Temple as a child, and grew to maturity there, being fed by an angel. "1 Unlike the High Priest of the Temple, who only entered the Holy of Holies on one single occasion a year, Mary lived there, and indeed tradition declared that her feet had never touched any other ground than its paving. Mystically, she was already destined to be the equivalent of both the Tabernacle and of its sacred contents. Indeed her whole life until she reached maturity was seen in medieval thought as preparation for the time when her body would itself become the Tabernacle in which the New Dispensation, her son the Messiah, would reside.

We have already seen that Theodulf, like any other member of the Visigothic Church in the eighth century, would have been aware of the cult of Mary, and would have grown up in an atmosphere steeped in Marian devotion. The foundations of Mary's cult in the West had been laid centuries earlier, even before the Council of Ephesus had declared her to be the Mother of God. In fact, the cult of the Virgin and the theology of Mary had been outlined by the early Fathers of the Church. It has been said, with reason, that Ambrose (d. 397), Augustine (354-430), and Jerome (ca. 342-420) "determined the course of western mariology for centuries to come." 42 It was these Fathers who first designated Mary a saint, and Ambrose was the first to use the title "Sancta" for her. This defined her role as the "new Eve," and expounded her role as a metaphor for the
Church. These Fathers wrote extensively about her virginity and its continuation during and after the birth of her child. They also speculated about her death. Theodulf, as we know from his own words in his poem De libris, was steeped in the works of Ambrose, Augustine, and Jerome, for he lists them among the Fathers whose works he read "very often," even "by night and day." 43

The presence of the cult of Mary in earliest Visigothic times in Spain is borne out by the writings of the Spanish Fathers. Among them was bishop Isidore of Seville (d. 636), whose work on the Ark as an allegory of the Church has already been mentioned, and who also had a place in Theodulf's De libris. It is to Isidore that the early prayer Pie et exaudibilis, which is directed to Christ through the intervention of the "blessed and glorious ever-Virgin Mary," is usually attributed in the books of private prayer, the Libelli Precum, which flourished in Spain as adjuncts to the Psalter. ${ }^{44}$ Theodulf's familiarity with Isidore's works is proved by his use of quotations from them in his own writings, in both the Opus Caroli Regis and his De Spiritu Sancto. ${ }^{45}$ Theodulf's poem De libris does not specifically mention Ildefonsus, bishop of Toledo (657-67), whose devotion to Mary is recorded in early biographies. His Marian devotion was such that the Virgin appeared to him while he was at prayer, and he celebrated her virginity in a well-known work, De Virginitate perpetua beatae Mariae. ${ }^{46}$ It seems likely that Theodulf was aware of Ildefonsus's work, despite his omission from De libris, which might conceivably be explained by the needs of the poetic form and the metre. ${ }^{47}$

Ildefonsus is believed to have been responsible for the collection of seventh-century prayers assembled in the earliest surviving Visigothic liturgical manuscript, the Orationale Visigothicum. ${ }^{48}$ This included a group of thirty-five prayers intended for use on the Virgin's feast day, the 18th of December in the Visigothic Church. Some of these, numbered as 202, 209, 222, and 233, addressed the Virgin directly, in the first person, and others were collective, and thus adapted for liturgical use. These prayers must also have been familiar to Theodulf, since he was raised in the Visigothic liturgy.

There is also evidence that the cult of the Virgin grew steadily throughout the Christian world outside Spain in the sixth to eighth centuries. This growth was expressed in a proliferation of feast days to celebrate the events of her life. The first of these new feast days dates to 542, when the Emperor Justinian inaugurated a feast for the Virgin Mary in Constantinople in thanksgiving for the end of a devastating epidemic of bubonic plague, which was believed to have been halted by her direct intercession. ${ }^{49}$ This feast, hitherto known only at Jerusalem, commemorated the Virgin's Purification in the Temple forty days after the birth of her child as required by Jewish law, ${ }^{50}$ as well as Christ's Presentation in the Temple. ${ }^{51}$ The same feast 
was later inaugurated in the Roman Church on the order of Pope Sergius I (687-701), one of the so-called "Eastern popes" who dominated the papacy for almost a hundred years from the mid-seventh century. Pope Sergius also introduced three other Marian feasts, those of the Annunciation, Nativity, and Dormition, as described in his biography in the Liber Pontificalis. 52 These four feasts were the most numerous granted to any of the saints. The dates on which they were celebrated came to be adopted by the Visigothic Church, which harmonized its Marian feasts with those of Rome: they would eventually be celebrated throughout the West, including the Carolingian lands.

Thus the cult of Mary can be firmly placed within the Church in the West from its earliest days as an organized entity, when the Fathers debated the theology surrounding the Virgin, through a period of growth of personal devotion and prayers to Mary, most notably in Spain, which led eventually to a mainstream situation, where devotion to the Virgin became the norm in the Roman Church as well. The young Theodulf will hardly have been able to escape the atmosphere of Marian devotion in Spain, where private prayers to her had not only become more frequent in Visigothic times but had also been formalized for use in the liturgy. He had the religious background to have formed a devotion to the Virgin Mary in his youth, and was not averse to allegorical interpretation. Was Mary seen as an allegorical equivalent to the Ark of the Covenant in the West or in Spain in or before the time of Theodulf? Could this idea have gained acceptance before Theodulf had the mosaic constructed that illustrates it?

Elisabeth Revel-Neher, in her monograph on the Ark of the Covenant, claimed that the earliest texts to expound the idea of Mary as Ark of the Covenant all originated in the works of the Greek Fathers, as late as the middle of the sixth century. ${ }^{53}$ These ideas would be incorporated in the Synodicon Vetus of the orthodox Church, a statement of faith compiled in connection with the Second Council of Nicaea, in 787, which drew upon earlier sources, as we have seen. This decree lists the prefigurations from the Old Testament that had been used for Mary during the period of iconoclasm, but which were now obsolete. The list includes the Ark of the Covenant. ${ }^{54}$ However, there is convincing evidence that these ideas were already current in the West in the time of the Fathers, and seem to have originated there. Bound up as an appendix to Ambrose's works in the Patrologia Latina is a group of sermons that had formerly been attributed to Ambrose, but are now given to his less well-known contemporary St Maximus of Turin. ${ }^{55}$ Maximus was Bishop of Turin in the earliest years of the fifth century, and died when both Honorius (r. 395-423) and Theodosius II (r. 408-50) reigned, that is, between 408 and $423 .{ }^{56}$ As long ago as the late seventeenth century some forty of these sermons were singled out as Maximus's work by the Maurist scholars who prepared the volume. This opinion has been confirmed by recent scholarship, especially that of Almut Mutzenbecher. She has assembled the sermons, together with those from other manuscripts, ${ }^{57}$ in the definitive corpus of the bishop's work. ${ }^{58}$ This corpus supercedes Bruno Bruni's edition, first published in 1784 , and now reprinted as volume 57 of the Patrologia Latina, which included two hundred and thirty-four homilies attributed to Maximus. ${ }^{59}$ Mutzenbecher has narrowed this down to a total of one hundred and six sermons, which she endorses as certainly genuine.

The most important of Maximus's sermons in the context of the Virgin as Ark of the Covenant is Sermo 42 in the Maurists' collection. This sermon is universally accepted as the work of Maximus. ${ }^{60}$ In it he explicitly compares Mary to the Ark of the Covenant. He suggests that just as King David danced and sang with joy in front of the Ark, ${ }^{61}$ Christians should rejoice at the marriage of Christ and his Church. Maximus continues by stating that the Virgin Mary is to be thought of as the Ark: "Ante arcam ergo saltavit propheta David: arcam autem quid nisi sanctam Mariam dixerimus?" "Accordingly the prophet David danced in front of the ark: however, what ark other [than] Saint Mary would we speak of?") Maximus buttresses his argument by comparing the tablets of the Law contained in the Ark with the heir of that testament, (the child) borne by Mary; moreover, whereas the Ark contains the Law, which is the Voice of God, Mary contains the Gospel, which is the True Word (the Logos). Maximus continues by equating the gold that shines on the Ark both inside and outside to the brilliant radiance of Mary's virginity. This latter, Maximus continues, is heavenly gold in contrast to the mere earthly gold that adorns the Ark. ${ }^{62}$ Both these concepts, Mary as the container of the New Dispensation, and Mary radiant with the gold of her virginity, are illustrated in Theodulf's apse mosaic, with the Ark as a container that gleams both inside and out with the gold of mosaic.

The association of this text with the works of St Ambrose, as well as the close proximity in both time and space of Maximus to the Milanese bishop, suggests that the relationships between the two authors and their works should be explored. This is especially important in view of De libris, the poem in which Theodulf lists the books he had read author by author. ${ }^{63}$ We have seen that Ambrose was among the Fathers of the Church whose works he read and pondered over, though there is no mention of Maximus in the poem. Could the latter have been a member of Ambrose's circle, or aware of his work? Could they have been acquainted with each other? Could Maximus have been one of the many Fathers whose works Theodulf had read, but whose names were too numerous to include in his poem? ${ }^{34}$ As with Ildefonsus, the omission of Maximus's name does not necessarily imply that Theodulf was unaware of his works. It could equally mean that he courted poetic brevity.

The first two of these questions have interested Lino Spinelli. 
He has pointed out that while Ambrose employs many allegories of the Virgin in his writings, the Ark of the Covenant is not among them, although the closely related allegories of the Virgin as the Tabernacle and the Virgin as the Temple are expounded by both Ambrose and Maximus. ${ }^{65}$ In addition, Maximus compares her to manna, another of the sacred contents of the Ark itself. ${ }^{66}$ In fact, both bishops employ many allegories in their study of the Virgin and delight in finding connections between Old and New Testaments that can be interpreted as her prefigurations. Ambrose and Maximus were near contemporaries and near neighbours in their Sees of Milan and Turin. ${ }^{67}$ Spinelli has investigated the possibility that they knew each other, and the probability that Maximus's work was influenced by Ambrose. He maintains that since Ambrose was a leader for his times in the theology of the Virgin Mary, at the very least his ideas and his works will have circulated in Turin, and been known by Maximus. Indeed, Maximus cires Ambrose in forty-nine of his one hundred and six sermons. ${ }^{68}$ Moreover, when he mentions the Virgin Mary, he draws upon the ideas of St Ambrose, as expressed in his De virginibus and Exposititio evangelii secundum Lucam. ${ }^{69}$

In the West, where the fifth and sixth centuries saw renewed interest in the role of Hebrew tradition in the origin of the Christian faith, this interest resulted in the appropriation of some of these traditions by the Roman Church. For example, Pope Leo I asserted, basing his argument on St Paul's epistle to the Hebrews, ${ }^{70}$ that the role of the High Priest had been inherited by the Pope. ${ }^{71}$ The dedication of a building in the Roman Forum as the church of SS Cosma e Damiano may also be an example of renewed interest in Hebrew tradition and history, for this was the site where the treasures of the Jewish Temple in Jerusalem had lain for almost half a millennium until carried off by the Vandals in $455 .{ }^{72}$ The founding of the feast days which celebrated Mary's life and her passing into Heaven also spurred a revival of interest, in terms of Old Testament precedents, in the events that were celebrated. In the East, especially, there was a revival of Marian devotion, which was expressed in the search for her typological equivalents. Thus the Virgin Mary came to be compared in the East as well as the West with those quintessentially Hebrew symbols, the Temple, the Tabernacle, and the Ark of the Covenant. These typological equivalents were to pass into the liturgy of the Byzantine Church and its prayers.

Further evidence for the sources that may well have influenced Theodulf's thought on the allegories of the Virgin can be found in a later section of De libris, in which he records the Christian Latin poets that he had read. He writes, "My attention was not slow duly to turn to the fathers whose names are written below for you to see: brilliant Sedulius, Paulinus, Arator, Avitus, Fortunatus, as well as thundering Juvencus, and the poet who was capable of composing many pieces in different metres
- Prudentius, my fellow-countryman."73 Among this list of Christian poets whose work Theodulf had studied, the majority wrote poems in honour of the Virgin Mary. In fact, Sedulius, Paulinus, Avitus, Fortunatus, Juvencus, and Prudentius all left poems in her praise, and many of them were written in the form of prayers.

Barré has collected some of these in his Prières anciennes de l'Occident à la Mère du Sauveur. ${ }^{74}$ Among them, Paulinus of Nola (d. 431), in his Carmen VI, adopts the earliest mode of salutation of the Virgin, elaborating on the words spoken to her by the angel Gabriel at the Annunciation, and on her reply to him. ${ }^{75}$ The Spanish priest Juvencus (ca. 330) also elaborated on the words of Gabriel and of Elisabeth, mother of the Baptist, in his poem Liber Evangeliorum, with the merest trace of the poem being an intercession; ${ }^{76}$ and an anonymous fourch-century poet, once mistaken for St Ambrose, wrote a poem elaborating on the words exchanged by Mary and Gabriel, which ends with an exhortation to the reader to pray to the Virgin. ${ }^{77}$ By contrast, Sedulius (425-50) addressed the Virgin directly in his Carmen Paschale. ${ }^{78}$ Sedulius's words, in his later prose version, passed directly into the Roman liturgy, where the Introit to the Feasts of the Virgin, as well as several antiphons, is drawn from his text. ${ }^{79}$ Prudentius, Theodulf's fellow-Spaniard, also wrote poetry in honour of the Virgin: both his Apotheosis and his Cathemerinon devote passages to her. ${ }^{80}$

But it is in the work of Venantius Fortunatus (d. 601) that we find the clearest evidence among the Latin poets read by Theodulf that the Ark of the Covenant was a current allegory in the sixth-century West. Fortunatus wrote many poems addressed to the Virgin Mary, among them In Laudem sanctae Mariae et matri Domini, "In praise of Saint Mary and the Mother of the Lord." This poem contains a stanza addressing her as "shining ark and powerful reliquary." This is the clearest of all the references in Theodulf's sources to the Virgin as Ark of the Covenant. ${ }^{81}$ Unfortunately, the limitations of poetic form of $D e$ libris do not allow us to know for sure which manuscripts of Fortunatus's work Theodulf had consulted, and, furthermore, whether any of them had included In Laudem sanctae Mariae. All we can say is that the library, or libraries, available to Theodulf in his youth, which he extols in his poem, had contained a great variety of works. This library, if in Spain, has long been dispersed. ${ }^{82}$ Nor do we know whether De libris was written in the period before or after Theodulf's move in 781 to the Carolingian court at Aachen, though it does seem likely to have been a product of the 780s. At this time the court was the centre of a group of poets, among them Alcuin, whose catalogue poem closely resembles Theodulf's De libris. ${ }^{83}$ At the court, too, a set of works have been shown to "form a definable school canon," and in Peter Godman's words, to have been the basis for "a shared literary culture." 84 Several Carolingian manuscripts have 
survived with the works of this canon, among them MS C74 of the Ambrosiana Library, which includes Fortunatus's Vita Martini followed by a section of In Laudem sanctae Mariae. This juxtaposition appears to have been common, if the six surviving manuscripts of In Laudem sanctae Mariae form a representative group. ${ }^{85}$ Theodulf's contemporary Alcuin made great use of Fortunatus's Vita Martini in his poetry, most of which appears to have been written while he was at Aachen in the 780s. It therefore seems probable that such a manuscript was available at court, and that Theodulf could well have seen Fortunatus's In Laudem, with its Marian allegory, there. It was also in the Vita Martini that Fortunatus's poetic catalogue occurred, which itself may well have been a major influence on the two poets. ${ }^{86}$

It is interesting to compare the directions that the cult of Mary took in the Eastern Church with the significance that was attached to her typological equivalents in the West. We have already seen that the earliest surviving Eastern writings to equate Mary with the Ark of the Covenant date from a century and a half after Bishop Maximus wrote his sermons. They are the work of Romanos Melodus (d. after 555), who preached a sermon on the Nativity and one on the Presentation in the Temple, ${ }^{87}$ Andrew of Crete (ca. 660-740), and John of Damascus (ca. 675-749), who took up the idea of the Virgin as Ark in the eighth century. ${ }^{88}$ By the end of that century, this allegory was widely accepted in the East. The near contemporary of Theodulf, Tarasius, Patriarch of Constantinople from 784-806, who presided over the Council of Nicaea II in 787, drew upon the earlier writings. Among his sermons, one lists the prefigurations of the Virgin in almost identical terms to the list that Andrew of Crete had drawn up in his sermon on the Presentation of the Virgin. ${ }^{89}$ Apparently, Theodulf had little knowledge of Greek, and may well have been unaware of this literature in the Greek language, though his De libris shows that he had studied Greek texts such as the works of St John Chrystostom that were available in Latin translation. As Bishop of Orléans, though, he will certainly have preached sermons for the Marian feast of the Purification of the Virgin, and will have explored whatever literature on the subject was available to him.

Thus there was enthusiasm in seventh- and eighth-century Byzantium for the allegories of the Virgin at the highest level of the church hierarchy. Not surprisingly, therefore, Elisabeth RevelNeher has been able to trace the spread of veneration of Mary as Ark of the Covenant in the rituals of the liturgy of the Byzantine Church. She gives some striking examples from the Sunday vespers, from the sticheres (liturgical hymns attached to the Psalms) and the orthros, or morning office, and above all, from the prayers offered on the festival commemorating the Presentation of the Virgin. ${ }^{90}$ Evidently in the East the typology of Mary as Ark of the Covenant was well known, and in widespread use by the eighth century. And these Byzantine ideas are believed to have spread independently through North Africa into the liturgy of Visigothic Spain. This, as we have seen, had already arrived at a higher level of devotion to Mary, in both private prayer and the public liturgy, than in the Roman Church, which lagged behind in this respect. In fact, Revel-Neher was unable to discover precise texts in western sources to confirm that the allegory of Mary as the Ark was important in the Roman liturgy used in Carolingian Gaul. Despite this, the cult of the Virgin had been on the rise in the West ever since the Syrian Pope Sergius I in the late seventh century inaugurated four feasts in her honour in the Roman Church, and by the early ninth century, if not before, references to Mary would have been understood by all educated people, even when they were cloaked in allegory. Moreover, Theodulf's background makes it clear that he was raised in an environment that was even richer in references to Mary than the Carolingian court.

To recapitulate, he was alone among the inner circle at Charlemagne's court in being a Visigoth. He was born and raised in Spain (probably in Saragossa), where he grew up in the Visigothic liturgy. The Opus Caroli Regis has been attributed to his auchorship because its orthography, spelling, and liturgical phrases all reveal traces of the Visigothic traditions of his youth. ${ }^{9 !}$ These traditions had immersed him from childhood in the literature of Marian devotion as expressed in the richness of allegory, and his childhood in Spain must also have accustomed him to the many prayers to the Virgin that characterized the Spanish liturgy. There, in contrast to the Roman rite, "many prayers were directed to the saints or the Virgin, and not only to God the Father or to Christ." 22 Among the thirty-five prayers or orations set out for the feast of her Conception on December 18, for example, was one (no. 933) which hails the Virgin's womb as the true Temple. Evidently the ancient Visigothic rite had been influenced by ideas from the East and diverged from the Roman practice in many respects, including its more developed cult of the Virgin.

We have already seen that Theodulf's own writings tell of the authors that he loved to read and ponder over by night and day. His De libris was in the form of a poetic catalogue, which was a well-established literary form that he shared with Alcuin, and that was adopted from the Christian Latin poets, among them Venantius Fortunatus. Evidently Theodulf was a voracious reader. He read the Church Fathers: Gregory the Great, Augustine, Hilary of Poitiers, Leo the Great, Jerome, Ambrose, Isidore, John Chrystostom, Cyprian, and others, among them Bede. ${ }^{93}$ Some of these thinkers, as we have seen, developed allegorical themes, including that of the Ark of the Covenant. In addition, his reading included the classical poets, among them Ovid and Virgil (in whose writings he saw pagan prefigurations of the Virgin Mary as Justice). He had also studied the Christian poets, who included both the Spaniard Prudentius and, closer to 
Theodulf's day and adopted homeland, Venantius Fortunatus. Fortunatus, a native of Valdobbiadene in the foothills of the Veneto, had studied in Ravenna, which as the Exarchate was under Byzantine control. It was also obviously a gateway through which Eastern ideas could enter Italy, just as Fortunatus's works were to diffuse these ideas throughout the West. We have already seen that his poem In Laudem sanctae Mariae, with its stanza addressing her as a "splendid ark and powerful reliquary," is evidence of the interest of the Christian Latin poets in this allegory. ${ }^{94}$ We have no way of knowing for certain whether Theodulf read this poem, or whether the copy of Fortunatus's poems that he had studied even contained it. But it seems reasonable to propose that his background and education would have prepared him to understand the Old Testament image over the altar of his chapel as a prefiguration of what was to come in the Christian revelation. This would hold true whether the image symbolized Christ, the New Dispensation; the Church; or the Virgin, Mother of God, Ark of the Covenant and instrument of the Incarnation. All of these meanings could conceivably have co-existed as allegorical interpretations of the aniconic image that he chose for the apse of his chapel, beneath which the sacred mysteries would have been celebrated.

In conclusion, it now seems certain that Theodulf, as a child of his times and a learned man proud of his heritage, was steeped in the devotion to the Virgin Mary that was characteristic not only of his Visigothic background, but also of the Carolingian court, where Charlemagne himself had paid tribute to the Virgin by naming her as patron of his palace chapel. The problem for Theodulf became one of reconciling his iconophobe ideas with his personal and naturally acquired devotion to the holy figures of the Christian faith, among them Christ's mother, the vehicle of the Incarnation. At this point, it is worth considering that approximately fifteen years had elapsed between Theodulf's writing of the Opus Caroli Regis in 790-93 and his building and decoration of the private episcopal oratory at Germigny-des-Prés in 806, with its prominent representation of the Ark of the Covenant above the altar. We must return to the initial question posed by this paper: why did Theodulf choose to display the image of the Ark of the Covenant in the chapel's most prominent position, the conch of the apse? Ann Freeman has noted that "one can see why this image - pre-eminent among images for the wealth of its implications - came naturally to [Theodulf's] mind. It may be that the apse mosaic at Germigny represents the most enterprising and imaginative attempt in Western art to invoke holiness by implication, iconographically."'5s During the fifteen years that had elapsed since the Opus Caroli Regis, he may well have modified his iconophobic views and deepened his understanding of the meaning of images and their functions. One may also suppose that Theodulf may have acquired knowledge of the text of the Sec- ond Council of Nicaea, which he had previously seen only in a corrupt translation. ${ }^{96}$ Perhaps he then realized that veneration, rather than adoration, was the official attitude of the Council on images. He showed a rigid and literalist position in book II of the Opus Caroli Regis, written in the early 790s: "if images may be likened to the ark of the Lord, they would have to have a propitiatory, as it also had, and that fearful oracles be delivered from them. But no oracles have ever come from images; therefore, they are not to be equated with the ark of the Lord." 97 However, he moved to a compromise position in book III. There he admitted that "maybe learned men can avoid adoring images by venerating not what they are but what they represent. Nevertheless, in so doing they create a pitfall for the unlearned, who venerate and adore only what they see. ${ }^{\prime 8}$ It is difficult to imagine a setting for the mosaic image of the Ark of the Covenant that would be more frequented by learned clerics and theologians than the chapel of a bishop's palace. Conversely, this private space was unlikely to allow entry to unlettered and unsophisticated lay people, suggesting that the iconography of Theodulf's apse mosaic would not constitute a danger to people of simple faith. But for Theodulf himself and his clergy the route of understanding was many layered, as the image reminded them of the many allegories that could simultaneously be understood within an image, prefigurations that had been suggested and, as it were, authenticated by the writings and sermons of the Church Fathers. We have seen that these individuals, who had laid down the accepted interpretations of the scriptures, had searched for typological equivalents of Christ, his Mother, and the Church itself. These allegories were in widespread use by the ninth century. It is unlikely that Theodulf would have limited himself to only one or two of the many possible allegorical meanings that had been attached to the Ark of the Covenant by theologians in the West, in Visigothic Spain, and in Byzantium. Rather, by placing this richest of all images in his apse, he allowed himself choice in his meditations. He could contemplate the original, the Ark itself that represented the presence of God among the Hebrews and contained the Word of the Law as revealed to Moses on Mt Sinai. In addition, he could go far beyond the literal meaning, and while pondering the words of the Fathers and of the poets who discussed the meaning of the Ark in Christian terms, he could understand its relevance as a prefiguration of the Virgin, the means whereby the Incarnation of Christ had come to pass, and with it the hope of salvation for every Christian soul.

\section{Acknowledgments}

I presented a preliminary version of this paper at an annual "work in progress" seminar of the Medieval Art Research Group at the University of Victoria. I benefited greatly from fellow- 
members' discussion and criticism. John Osborne also kindly read a previous version of this article. A reviewer for RACAR gave me some thoughtful suggestions, which I have endeavoured to incorporate.

Much of the work on which this article is based was carried out at the library of the British School at Rome, the Hertziana Library there, the Vatican Library, and the Warburg Library in London. Final editing was carried out in Victoria and at the University of Washington's Whiteley Centre at Friday Harbor, Washington. I would like to thank all these institutions both for their excellent facilities and for their courteous assistance.

Notes

1 In addition to Theodulf's undated inscription in the apsc mosaic, given in note 10 , dated inscriptions on the piers on either side of the apse were recorded by Jean Hubert, "Germigny-des-Prés," Congrès archéologique de France, 93e session, Orléans, 1931, 530, n. 3. They read: "III NONAS JANUARII DEDICATIO HUIUS ECCLESIAE. ANNO INCARNATIONIS DOMINI DCCC ET VI SUB ONVOCATIONE SANCTAE GENVRAE ET SANCTI GERMINI." Annc-Orange Poilpré, "Le décor de l'oratoire de Germigny-des-Prés: l'authentique et le restauré," Cahiers de civilisation mediévale, XLI (1998), 281-97, esp. 283-84 and n. 14, discusses these carly and lost inscriptions, along with some from the nineteenth century, which are forgeries. An undated inscription, reading "HAEC IN HONORE DEI THEODULFUS TEMPLA SACRAVI - QUAE DUM QUISQUIS ADES, ORO, MOMENTO MEI" ("I, Theodulf, consecrated this temple in honour of God; while you approach it, whoever you are, remember me, I pray"), is known from the Catalogus abbatum Floriacensium, a late ninth to early tenth century source in Stephani Baluzii Miscellanea, I (1761), 79 (not available to mc), and also in J.P. Migne, ed., Patrologia Latina [PL] (Paris, 1844-79), CXXXIX, cols. 579-84, esp. 581-82. Trans. in N. Alexandrenko, "The Poetry of Theodulf of Orleans: A Translation and Critical Study," Ph.D. diss., Tulane University, 1970, 285.

2 See Elisabeth Revel-Neher, Le signe de la rencontre. L'arche d'alliance dans l'art juif et chrétien du second au dixième siècles (Paris, 1984), 184-85: "Thème unique du décor absidal, thème original puisqu'il n'a ni précédent ni suite ..."

3 Ann Freeman and Paul Meyvaert, "The Meaning of Theodulf's Apse Mosaic at Germigny-de Prés," Gesta, 40 (2001), 125-40, esp. 129-30 and fig. 2. See also P. Meyvaert, "Maximilien Théodore Chrétin and the Apse Mosaic at Germigny-des-Prés," Gazette des Beaux-Arts, 143, (2001), 203-20, esp. 211-12 and fig. 4.

4 See Poilpré, "Décor," 285, for loss of vertical line, also 291-92 and 286, fig. 6, describing the top of the box.

5 Meyvaert, "Théodore Chrétin," 212, and figs. 4 and 5.

6 Poilpré, "Décor," 286 and fig. 6, showing the arcas of golden mosaic remade in the nineteenth century.

7 Theodulf, Abbot of Fleury as well as Bishop of Orléans, had access to Bede's work in the monastic library at Fleury, which is known to have owned a copy of Bede's related text, De Tabernaculo. See M.L.W. Laistner and H.H. King, A Hand-List of Bede Manuscripts (Ithaca, 1943). According to A.C. Holder, ed. and trans., Bede: On the Tabernacle (Liverpool, 1994), p. xxii, Bede's On the Temple contained references to his earlier volume, and it is likely that the early medieval monastic library would have owned both works.

8 For Theodulf's work, see Ann Freeman, ed., Opus Caroli Regis contra Synodum (Opus Caroli Regis), Monumenta Germaniae Historica [MGH] (Hanover, 1998), which supercedes Hubert Bastgen, ed., Opus Caroli Regis sive Caroli magni, MGH (Hanover and Leipzig, 1924). Freeman has found that the title Opus Caroli Regis contra Synodum has precedence over the previous Libri Carolini. For Theodulf's borrowing from Bede, see Freeman, Opus Caroli Regis, 198-203.

92 Chronicles 3:10-15.

10 Freeman and Mayvaert, "Meaning," 31, and n. 47.

11 Tables of the Law: Deuteronomy 4:13; Manna: Exodus 16:32; Rod of Aaron: Numbers 17:16-26. Manna was already in the sixth century considered to be a prefiguration of the Virgin Mary. See S. Maximus Taurinens, in PL, LVII, 330: "Maria cst manna subtilis, splendida, suavis et virgo, quae velut coelitus veniens, cunctis ecclesiarum populis cibum dulciorum melle defluxit."

12 I thank RACAR's reviewer for sharing ideas about the Germigny mosaic with mc.

13 This theme is trcated in Theodulf's poem "Quam ob rem cicatrices, quas Dominus in passione suscepit, in resurrectione obductae non sint," which can be translated as "Why the scars of Christ's Passion werc not healed in his Resurrection" or, in Helen Waddell's translation, "Wherefore did the scars of Christ's Passion remain in the body of his Resurrection?" See Waddell, Poetry of the Dark Ages (New York, 1948), 21-22; and also Freeman and Meyvaert, "Meaning," 133-34.

14 Trans. Alexandrenko, "Poetry of Theodulf," 286. Hubert, in "Germigny-des-Prés," gives a literal transcription: "ORACULUM SCM ET CERUBIN HIS ASPICE SPECTANS ET TESTAMENTI EN MICAT ARCA DEI/ HAEC CERNANS PRECIBU QUE STUDENS PULSARE TONANTEM THEODULFUM VOTIS IUNGITO QUESO TUIS." Poilpré, in "Décor," 284, n. 16, gives the expanded Latin version: "ORACLUM SANCTUM ET CERUBIN HIC ASPICE SPECTANS ET TESTAMENTI EN MICAT ARCA DEI - HAEC CERNENS PRECIBUS QUE STUDENS PULSARE TONANTEM THEODUI.FUM VOTIS JUNGITO QUESO TUIS."

15 See Ann Freeman's arguments with regard to Theodulf's authorship in her "Theodulf of Orleans and the Libri Carolini," Speculum, XXXII (1957), 663-705, esp. 688-703.

16 Tarasius, patriarch of Constantinople from 784-806, "embarked on a policy of restoring good relations between the Byzantine Church and the West and persuaded the Empress to convoke, in harmony with the pope, Hadrian I, a general council which sat in Nicaea in 787." See "Tarasius," in The Oxford Dictionary of the Christian Church (2nd ed.), eds. F.L. Cross and E.A. Livingstone (Oxford, 1974), 1340. 
17 Theodulf, Opus Caroli Regis, chapter 1:15 for the Ark and the Cherubim; chapter 1:20 on the Cherubim and their allegorical meaning as the two Testaments.

18 For Freeman, ed., Opus Caroli Regis, see note 8. See also her "Theodulf of Orléans," 700.

19 See Exodus, chapter 25, and 2 Chronicles, chapter 3.

20 See J.N. Hillgarth, "Popular Religion in Visigothic Spain," in Visigothic Spain: New Approaches, ed. Edward James (Oxford, 1980), 3-60, esp. 32-33, and note 5 on 32, and notes 1 and 2 on 33. Hillgarth notes that quotations from the Old Testament predominate by a good margin in the writings of seventh-century Spanish bishops in comparison with their New Testament references.

21 Freeman and Mcyvaert, "Meaning."

22 Lawrence Nees recognized Christ as the Ark of the Covenant in the Maiestas Domini miniature, fol. 12v. of the Gundohinus Gospels (Autun, Bibliothèque Municipale, MS 3), dated ca. 754, where Christ's enthroned figure is flanked by cherubim (inscribed Cyrubin), with their wings raised and stretched out to touch each orher, as at Germigny and as in the Old Testament texts. See L. Nees, The Gundohinus Gospels (Cambridge, Mass., 1987), 186-88.

23 Revel-Neher, L'Arche, 62-67. Augustine, Quaestiones in Heptateuchum. Quaest. Exodi, Corpus Christianorum, 33, CIIII-CV (Turnhout, 1958), 121.

24 Gregory the Great, PL, LXXVI, Homily 25, col. 1191: "Et quid per due cherubim nisi utraque Testamenta signantur? Quid vero per propitiatorium nisi Dominus figuratur?"

25 Isidore, PL, LXXXIII, Quaestiones in Vetus Testamentum - In Exodum, col. $311 \mathrm{f}$, esp. chapter 45, "De urna aurea, et tabulis, et virga," and chapter 46, "De propitiatorio et cherubim," in which he proposes that the Mercy Seat prefigures the Incarnation of Christ, the Cherubim, and the Old and New Testaments.

26 See Theodulf's poem, "De libris quos legere solebam et qualiter fabulae poetarum a philosophis mystice pertractentur" ("Concerning Books which I used to Read"), MGH, Poetae latinae, I, 543,

27 See Freeman, Opus Caroli Regis, 53-56, for the sources of the Libri Carolini in Isidore.

28 The Fleury list of abbots (Catalogus abbatum floriacensium) ends with the fourteenth abbot, Theodulf. It reads: "At vero Theodulfus aulam a se constructam omnium conditori ac salvatori rerum Deo consecrans, Cherubin gloriae obumbrantia propitiatorium super altare ipsius artificiosissimo magisterio expressum his decoravit versibus." (The text in silver letters from the apse follows, as in note 1.) See Meyvaert and Freeman, "Meaning," 136, n. 10, quoting a twelfth-century manuscript from Moissac, BNF, MS lat. 1720, fol. 6v-7v. See also PL, CXXXIX, 579.

29 See A. Vignali, "Chiese e basiliche dedicate al Salvatore in Italia sotto i longobardi con particolare riferimento a quelle di Spoleto e Ravenna," Atti del $1^{\circ}$ congresso internazionale di Studi Longobardi (Spoleto, 1951), 505-16, esp. 506f. See also G. Mackie, "La Daurade: A Royal Mausoleum," Cahiers Archéologiques, 42 (1994), 17-34, esp. 23-24, for a summary of early ruler dedications to Christ Saviour.

30 R. Rey, "Le sanctuaire paléochrétien de la Daurade à Toulouse," Annales du Midi, LXI (1948-49), 249-73, esp. 264.
31 See Mackie, "La Daurade," 21-23.

32 Theodulf's origins are discussed in Ann Freeman, "Further Studies in the Libri Carolini," Speculum, 40 (1965), 274-78, esp. 276-78, arguing for Saragossa as his birthplace. Freeman suggests that Theodulf may have left Saragossa after the troubles of 781-82, when the Christian community there suffered extreme persecution under Arab rule.

33 See Mackie, "La Daurade," 23-24, for the history and iconographic programme of these mosaics.

34 It was suggested, but specifically rejected, by the anonymous author of the leaflet "Église de Germigny: la Mosaïque" (a visitor pamphlet available at the church) on the grounds that the mosaic should be in the north or south apse (where no mosaics have survived), rather than the east, to harbour this meaning. I have not found the source of this belief; indeed, images of Mary were frequently placed in the main (east) apse in the Early Middle Ages, see note 33, below. The statement reads: "Si la mosaïque du l'Arche était à l'abside nord ou sud elle aurait problement un symbolisme marial. On connaît les 'Litanies de la Vierge' et l'invocation 'Arche d'Alliance, priez pour nous.' A sa place, Marie, ayant 'porté' la Verbe, est arche d'alliance."

35 Other important early examples of lost apse decorations featuring Mary include S Maria Maggiore, Rome; the Basilica Suricorum of Bishop Symmachus at Capua Vetere; S Maria Maggiore, Ravenna; and S Sergius at Gaza (all dated before 536). They are discussed in Christa Ihm, Die Programme der Christlicher Apsismalerei vom vierten Jahrhudert bis zur Mitte des achten Jahrhunderts (Weisbaden, 1960).

36 For example, the early ninth-century image of Mary enthroned in the vault of the crypt chapel of the monastery of $S$ Vincenzo al Volturno, Molise. Her book displays her words from the Magnificat, "Beatus me dicent." The paintings are dated to the abbacy of Epiphanius (824-42). See Angelo Pantoni, San Vincenzo al Volturno e la cripta dell'abate Epiphanio (Montecassino, 1970), pl. 36.

37 The mosaics of these two churches are also illustrated in $\mathrm{Ihm}$, Programme, pl. XVI, and 60, fig.12 (Lythrankomi); also pl. XVIII (Kiti).

38 Freeman, "Theodulf of Orleans," 701, n. 153, quoting George M.A. Hanfmann, The Seasons Sarcophagus in Dumbarton Oaks (Cambridge, Mass., 1951), I, 204-5.

39 Many of these ideas are to be found in the works of the ninthcentury Abbot of Fulda and theologian, Rabanus Maurus (ca. 776 or 784-856) whose list of allegories, "Allegoriae in universam sacram scripturam," PL, CXII, cols. 848-1088, includes many for the Virgin. These include a castle, a mountain, wool, the marriage bed, a door, the sun, stars and earth, and, with special relevance to my argument, the Old Testament allegories: the Tabernacle (col. 1062), the Ticmple (col. 1064), and the Rod of Aaron (cols. 1064 and 1073). Earlier, in the sixth-century poem "In laudem sancte Mariae," Venantius Fortunatus describes Mary as the Way, a door, a wheel leading to the sky, a high lighthouse, a vase produced by the potter, more beautiful than all the rest, a magnificent candelabra enclosing the light of the Word, and many other poetic equivalents. See "In laudem sancte Mariae," in Venance Fortunat, Poèmes, 
trans. and ed. Marc Reydellet (Paris, 2004), 162-78, esp. 173-75. 40 Jean Gouillard, "Le Synodikon de l'Orthodoxie, Édition et Commentaire," Travaux et Memoires, 2: 1-316, esp. 48-51, for Greek text. For translation, see R. Cormack, "Painting after Iconoclasm," in A. Bryer and J. Herrin, eds., Iconoclasm: papers given at the Ninth Spring Symposium of Byzantine Studies (Birmingham, 1977), 147-65, esp. 153-55.

4] Two legends of Mary's infancy are translated into English by M.R. James in The New Testament Apocrypha (Oxford, 1924): the "Book of James" or "Protoevangelium," 38-49; and the "Gospel of PseudoMatthew," 70-79.

42 Mary Clayton, The Cult of the Virgin Mary in Anglo-Saxon England (Cambridge, 1990), esp. chapter 4, "Private prayer to Mary," 90121 ; see 100 and n. 43 for sources.

43 Theodulf of Orléans, "De libris," lines 1-6: "Namque ego suetus eram hos libros legisse frequenter / Extitit ille mihi nocte dieque labor..."

44 Henri Barré, Prières anciennes de l'Occident à la Mère du Sauveur, Dès origines a Saint Anselme (Paris, 1963), 30. See also PL, CI, col. 1387D, for "Pie et exaudibilis."

45 Opus Caroli Regis, III, 3; "De Spiritu Sancto," PL, CV, 271. Also see Freeman, "Theodulf of Orléans," 693-94.

46 Ildefonsus, De virginitate perpetua sanctae Mariae adversus tres infideles, in $P L, \mathrm{XCVI}$, cols. 556A \& 1387D. See also Bishop Cixila of Toledo (770-83) for his Vita of Ildefonsus, in PL, XCVI, col. 45 , in which he states that the Virgin presented Ildefonsus with a chasuble to reward him for defending her virginity. There is no contemporary confirmation of this miracle, according to Sister Athanasius Braegelmann, The Life and Writings of Saint Ildefonsus of Toledo, Ph.D. diss., Catholic University of America, Washington, D.C., 1942.

47 See Alcuin, De Pontificibus et sanctis ecclesiae Eboracensis, trans. by Peter Godman as Alcuin. The Bishops, Kings and Saints of York (Oxford, 1982), 122-27, esp. 126, lines 1561-62, in which the poet, listing the authors whose books Archbishop Aelberht had donated to his new basilica, St Sophia in York (121-27, lines 1519-68) concludes in 1558-62: "There, reader, you will find many others, teachers outstanding for their learning, art and style, who wrote many volumes with clear meaning. But to include all their names in this poem would take longer than poetic usage demands." The tradition of listing authors stretches back to Venantius Fortunatus, whose Vita S. Martini I, in $P L$, LXXXVIII, cols. 365-66, lines 14-25, contains a similar list of poets. Also sec Godman, ed., Alcuin, 124, note to lines 1551-54, which gives the text of this list, comparing it with Alcuin's in the lines above. Clearly Fortunatus's poem was the source of Alcuin's inspiration.

48 Orationale of Verona (Oracional Visigotico), V Verona, Biblioteca Capitolare LXXXIX, ed. D. José Vives, Monumenta hispaniae sacra, Serie Liturgica, I (Barcelona, 1946). This manuscript is dated before 711. See also Barré, Prières, 32-33.

49 "Candlemas," in Oxford Dictionary of the Christian Church, 229. See also Mary Clayton, Cult of the Virgin, 25-29, for the historical background of Marian feasts.
50 Leviticus $12: 1-4$

51 Luke 2:22-39.

52 L. Duchesne, ed., Liber Pontificalis, 3 vols. (Paris, 1886-92), 1: 376: "Constituit autem ut diebus Adnuntiatonis Domini, Dormitionis et Nativitatis sanctae genetricis semperque virginis Mariae ac sancti Symeonis, quod Ypapanti Greci appellant, letania exeat a sancto hadriano et ad sanctam Mariam populus occurrat." Raymond Davis, trans., The Book of Pontiffs (Liber Pontificalis) (Liverpool, 1989), 87.

53 Revel-Neher cited the writings of St Romanus Melodus and the early eighth-century Greek Fathers, Andrew of Crete and John of Damascus. See L'Arche, 53.

54 See Gouillard, Le Synodikon de l'Orthodoxie, 48-51, for Greek text; and Cormack "Painting after Iconoclasm," 153-55, for translation.

55 For all known information on St Maximus, see The Sermons of St. Maximus of Turin, trans. and annotated by Boniface Ramsey (New York and Mahwah, 1989), Ancient Christian Writers, vol. 50, esp. introduction, "The Life of Maximus," 1-12.

56 Hieronymus and Gennadius, De viris inlustribus, ed. Carl Albrecht Bernoulli (Frankfurt, 1968), Cap. XL, 76; trans. by Ernest Cushing Richards as "The Lives of the Illustrious Men" in The Nicene and Post-Nicene Fathers, series II, vol. 3, (New York, 1892, repr. 1996), 393.

57 Maximus's works were recognized by Jean Mabillon in the following manuscripts: Sessorianus 55/2099; Ambrosianus C. 98 inf., and Sangallensis 188.

58 Maximi episcopi taurinensis collectionem, sermonum antiquam nonnullis sermonibus extravagantibus adiectis, ed. A.Mutzenbecher, Corpus Christianorum, Series Latina, 23, (Turnhout, 1962).

59 Sancti Maximi episcopi taurinensis, Opera Omnia, in PL, LVII, ed. B. Bruni (Rome, 1784).

60 Sermones S.Ambrosio hactenus ascripti, in PL, XVII, Sermo XLII, cols. 709-12, "Increpatio ad plebem de eo quod scriptum est in Evangelio: qui habet, dabitur ei; et: cantavimus vobis, etc." (The Sermons of St. Maximus, trans. Ramsey, 104-7, and notes pp. 31113).

612 Kings 6:14.

62 PL, XVII, Sermo XLII, cols. 711-12: "Ante arcam ergo saltavit propheta David: arcam autem quid nisi sanctam Mariam dixerimus? Siquidem arca intrinsecus portabat Testamenti tabulas, Maria autem ipsius Testamenti gestabat haeredem: illa intra semet legem, haec Evangelium retinebat; illa Dei vocem habebat, haec Verbum. Verumtamen arca intus forisque auri nitore radiabat, sed et sancta Maria intus forisque virginitatis splendore fulgebat: illa terreno ornabatur auro, ista coelesti."

63 Theodulf's verses which include the Church Fathers read:

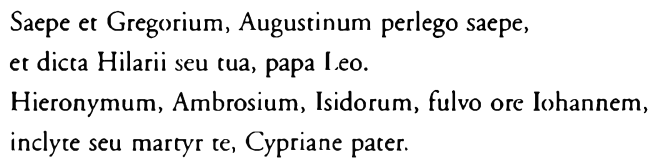

Theodulf, "De libris," lines 1-6.

64 Theodulf, "De libris," lines 7-8: "sive alios, quorum describere 
nomina longum est, / Quos bene doctrinae vexit ad alta decus."

65 Lino M. Spinelli, Maria nei sermoni di san Massimo vescovo di Torino (Vicenza, 1983), 90-91.

66 S. Maximus Taurinensis, in PL, LVII, Sermo 45, col. 330, B-C: "Maria est manna subtilis splendida, suavis et virgo, quae velut coelitus veniens, cunctis Ecclesiarum populis cibum dulciorum melle defluxit."

67 It is now accepted that Turin had two bishops named Maximus in the fifth century, allowing the earlier one to be identified both as author of the sermons and as a near-contemporary or even contemporary of St Ambrose.

68 Spinelli, Maria, 88.

69 Maximi episcopi Taurinensis, ed. Mutzenbecher, 169-72. See also Spinelli, Maria, 88, n. 4.

70 Hebrews 8:5-10 and 10:1.

71 See Leo I, in PL, LIV, Sermo III, Ch. I, 11; trans. C.L. Feltoe, The Letters and Sermons of Leo the Great, in Nicene \& Post Nicene Fathers, 12 (New York, 1895). See also chapter 8 on the chapels at the Lateran Baptistery, Rome, in G. Mackie, The Early Christian Chapel, Decoration, Function and Patronage (Toronto, 2003), esp. 211 and n. 92.

72 I am indebted for this idea to John Osborne, personal communication.

73 Cura decens patrum nec erat postrema piorum,

Quorum sunt subter nomina scripta, vide:

Sedulius rutilus, Paulinus, Arator, Avitus,

Et Fortunatus, tuque, Iuvence tonans;

Diversoque potens prudenter promere plura

Metro, o Prudenti, noster et ipse parens.

Theodulf, "De libris," lines 11-18. Theodulf's claim in line 18 to be a fellow-countryman of Prudentius, a native of Saragossa, has been taken as evidence that Theodulf too was a native of that city.

74 See Barré, Prières, 1927.

75 Paulinus, Carmen VI (Laus S. Iohannis), in PL, LXI, cols. 442-49, lines 118-23, and 151-58. Also Corpus scriptorum ecclesiastorum latinorum [CSEL], 30, ed. G. Hartel, (Vienna, 1894), 11-12.

76 Juvencus, Evangelicae historiae, I, cols. 71-75, in PL, XIX; J. Huemer, ed., CSEL, 24, 1891, 6-8.

77 Barré, Prières, 26, and n. 37. See also PL, XVII, col. 1202.

78 Sedulius, Carmen Paschale, II, esp. cols. 599-600, PL, XIX: "Salve, sancta parens, enixa puerpera Regem..." Also J. Huemer, ed., CSEL, 10, Quarti saeculi poetarum Christianorum (Vienna, 1885), $48-49$, and 201.

79 See Barré, Prières, 25.

80 See Prudentius, Collected Works, 2 vols., trans. H.J. Thompson (Loeb edition, 1949-53).

81 Venantius Fortunatus, "In laudem sanctae Mariae," in $P L$, LXXXVIII, 276-84, esp. col. 281, starting "O Virgo excellens":

\footnotetext{
Aula Dei, ornatus paradisi, gloria regni

Hospitium vitae, pons penetrando polos.

Arca nites, et theca potens gladii bis acuti,

Ara Dei assurgens, luminis alta pharos.
}

See also note 39 for French edition by Marc Reydellet,
82 Ann Freeman has suggested that this library may have been the one assembled by Braulio, Bishop of Saragossa (631-51), literary heir to Isidore of Seville and a famous book collector. This library contained both Christian and classical authors and may have survived intact into Theodulf's time: it is probable that Theodulf was a native of Saragossa. See Freeman, "Further Studies," 276-77; and for Braulio's library, Charles H. Lynch, Saint Braulio, Bishop of Saragossa (631-651) His Life and Writings (Washington, D.C., 1938), esp. chapter 4, "The Scholar," 149-58. See also n. 75, above, for evidence from Paulinus's own writings.

83 See Alcuin's catalogue of the books owned by Bishop Aelberht in his poem Versus de patribus regibus et sanctis euboricensis ecclesiae, in Godman, Alcuin, The Bishops, Kings, and Saints of York, lines 1520-68, esp. 1552-54.

84 See Godman, Alcuin, introduction, lxix, and n. 7 for sources.

85 Ambrosianus C74, fol. 63, as listed in Venantius Fortunatus, Poèmes, Livres ix-xi, Appendice "In Laudem sanctae Mariae," ed. and trans. Marc Reydellet. Among the six manuscripts that Reydellet cites, four place the Marian poem immediately after the "Vita S. Martini." These are Ambrosianus C74, Vaticanus Palatinus 845, Sangallensis 573, and Parisinus 8090.

86 See Venantius Fortunatus, Vita S Martini, I, cols. 365-66, lines $14-25$.

87 Romanos Melodus, Genuine Cantica, critical edition by P. Maas and C.A. Tympanis (Oxford, 1963).

88 See John of Damascus, Homélies sur la Nativité et la Dormition, introduction, trans., and notes by Pierre Voulet (Paris, 1963).

89 Text in SS Deiparae Praesentationem Oratio in SS Dei Matrem, Patrologia Graeca, 80 (Paris, 1857-87), col. 1490. See also RevelNeher, L'Arche, 57; and Mary Jerome Kishpaugh, O.P., "The Feast of the Presentation of the Virgin Mary in the Temple," Ph.D. diss., Catholic University of America, 1941.

90 Revel-Neher, L'Arche, 58-60.

91 See Freeman, "Theodulf of Orléans," 663-705. For the Visigothic liturgy, see Dom Louis Brou, "L'Antiphonaire wisigothique et l'Antiphonaire grégorien au debut du VIIle siècle," Annuario musical, V, (1950), 7f; and Dom Gregory Dix, The Shape of the Liturgy (London, 1945), 551f. See also "Mozarabic Rite," Oxford Dictionary of the Christian Church, 2nd ed., 947-48.

92 Hillgarth, "Popular Religion," 35.

93 See F.J.E. Raby, A History of Christian Latin Poetry from the Beginnings to the Close of the Middle Ages (Oxford, 1927), 171, on Theodulf of Orléans, ca. 760-ca. 821. MGH, Poet. Kar., I, 543.

Saepe et Gregorium, Augustinum, perlego saepe et dicta Hilarii seu cua, papa Leo.

Hieronymum, Ambrosium, Isidorum, fulvo ore Iohannum inclyte seu martyr te, Cypriane pater.

94 Venantius Fortunatus, Poèmes. See also Georges Gharib et al., Testi Mariani del primo Millenio, III, Padri e altri autori latini (Rome, 1990), 605-13.

95 Ann Freeman, "Scripture and Images in the Libri Carolini," in Testo e immagine nell'alto medioevo, Settimane di studio del centro 
italiano di studi sull'alto medioevo, 41, (Spoleto 1994), 163-96, esp. 182.

96 See noce 15 , above.

97 Frecman, Opus Caroli Regis, II, 26. Sec Herbert L. Kessler, Spiritual Seeing: Picturing God's Invisibility in Medieval Art (Philadelphia, 2001), 195, for Fnglish trans. and Latin text on 255, n. 36.
98 Freeman, Opus Caroli Regis, III, 16, 41 1, lines 15-20: "Nam etsi a docris quibusque vitari possit hoc, quod illi in dorandis imaginibus exercent, qui vidilicet non qui sint, sed quid innuant venerantur, indoctis camen quibusque scandalum generant, qui nihil aliud in his pretcr $[\ldots]$ id, quod vident, venerantur et adorant." 